\title{
Creation of Island Habitat in Jacksonville Harbor, FL
}

\section{US Army Corps of Engineers ${ }_{\oplus}$}

by Stephanie Groleau

INTRODUCTION. Jacksonville Harbor, in Duval County, FL, begins at the mouth of the St. Johns River where it empties into the Atlantic Ocean (Figure 1). The Federally authorized Jacksonville Harbor navigation project provides deep-draft vessels access to terminal facilities located within the City of Jacksonville. Jacksonville Harbor also serves the US Navy and the US Marine Corps.

The Jacksonville Harbor General Re-evaluation Report (GRR) is investigating deepening and widening the Federal navigation channel. The GRR will most likely identify about 20 million cubic yards (cu yd) of material to be dredged and placed. All of this new-work dredging material is Offshore Dredged Material Disposal Site (ODMDS)-quality, with most of this dredged volume assumed to be going into the Jacksonville Harbor ODMDS (Figure 1) because options for upland disposal are unavailable. This material could be more beneficially used to create complex island habitat in the St. Johns River, which would additionally save the GRR millions of dollars. This Coastal and Hydraulics Engineering Technical Note (CHETN) was prepared by the US Army Engineer District (USAED), Jacksonville (SAJ), as part of the Regional Sediment Management (RSM) program, to emphasize a least-cost and beneficial alternative for using dredged material not suitable for nearshore placement.

J ACKSONVILLE HARBOR SEDIMENTS. There are four designations of dredged material quality throughout Jacksonville Harbor:

1. Beach quality material, which has less than $10 \%$ fine sediments.

2. Nearshore quality material, which has more than $10 \%$ but less than $20 \%$ fine sediments.

3. ODMDS quality material, which is too fine for beach or nearshore placement and must pass testing for physical, chemical, and toxicological parameters according to Section 103 of the Marine Protection, Research, and Sanctuaries Act (1972).

4. Confined Disposal Facility (CDF)-only quality material, which is not suitable to be placed on the beach, nearshore, or within ODMDS, but which is not considered hazardous or toxic.

Figure 1 shows the Cuts of the Federal channel of Jacksonville Harbor. Typically, maintenance dredging material in the Entrance Channel-to-Cut 13 is beach quality, material in Cuts 14-to-42 is nearshore quality, material in Cuts 43-to-50 is offshore quality, and the rest of the material (Cuts 51-to-Terminal Channel, F, and G) is suitable for confined disposal only. Table 1 shows the approximate historical maintenance dredging quantity of material removed from each of these channel section (cu yd per year), and the quality of that material. Material quality is a limiting factor in placement options, but often SAJ chooses placement based on costs instead of the best use of the material.

AN UNTRADITIONAL APPROACH TO RSM. Many US Army Corps of Engineers (USACE) Districts and non-Federal sponsors are working toward developing innovative ways to incorporate RSM approaches beyond traditional beach and nearshore placement. A lot of material in navigation channels is not suitable for the littoral zone due to grain size but is ideal for creating wetland habitat, nesting areas for listed and endangered shorebirds, and essential fish habitat for juvenile fish and invertebrates in benefit of the Magnuson-Stevens Fishery Conservation and Management Act of 1996. 
ERDC/CHL CHETN-XIV-30

J une 2013

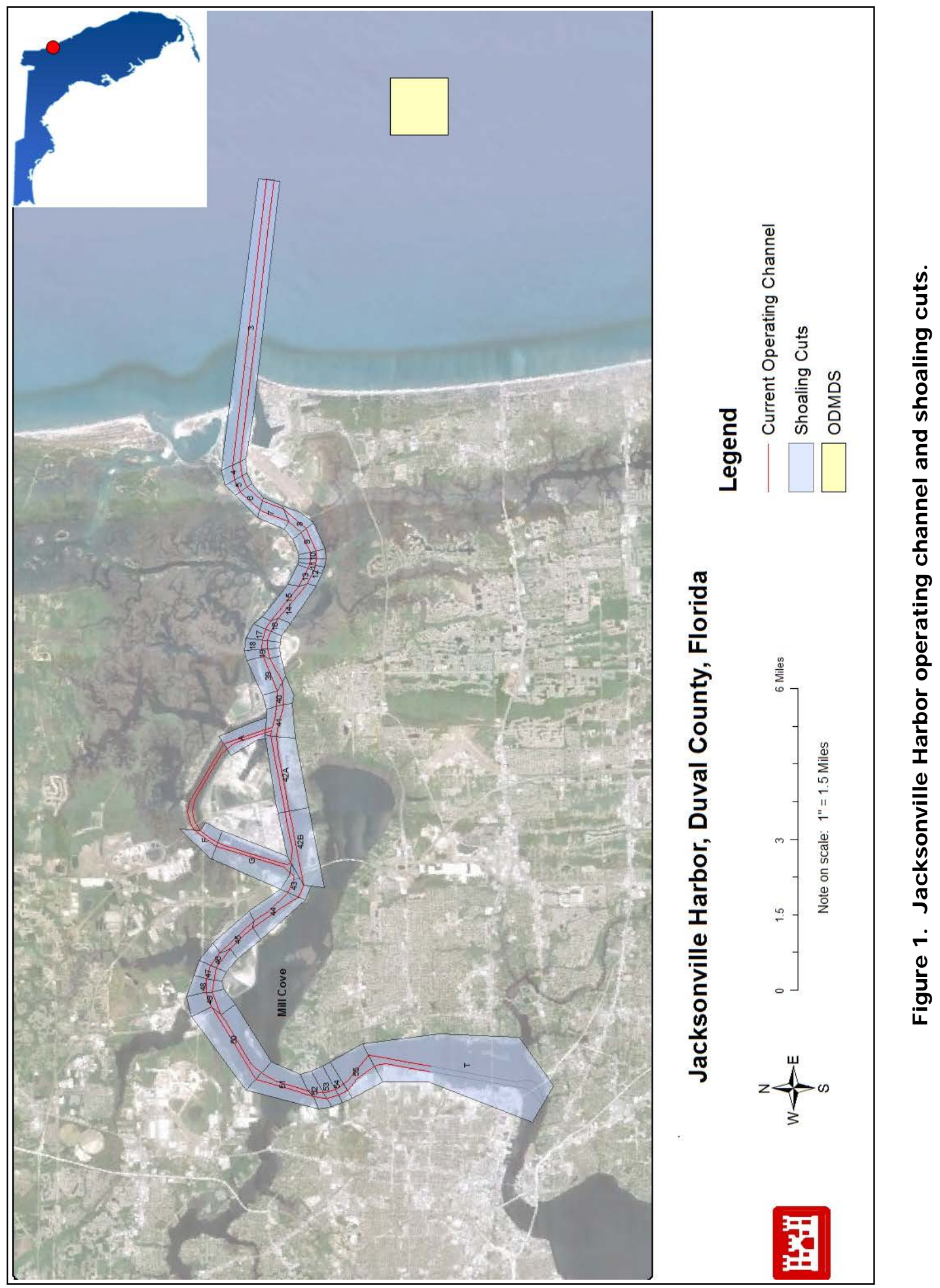


Table 1. Approximate Historical Maintenance Dredging Quantity and Quality by Channel Section (cu yd per year).

\begin{tabular}{|l|c|c|c|c|c|}
\hline Material Type & Cuts 43-TC & Cuts F and G & Cuts 14-42 & Cuts 3-13 & Total \\
\hline Beach/Nearshore Quality & 6,600 & 0 & 435,000 & 185,000 & 626,600 \\
\hline ODMDS Quality & 516,050 & 0 & 62,400 & 0 & 578,450 \\
\hline CDF-Only Quality & 43,350 & 146,600 & 0 & 0 & 189,950 \\
\hline
\end{tabular}

This has been accomplished with great success in a variety of circumstances. In partnership with the State of Maryland, the USAED Baltimore (NAB) used dredged material to create 180 acres of wetlands and mudflats for shorebird habitat, a 1-acre nesting habitat, and 118 acres of upland for songbird habitat as part of Hart-Miller Island. This island in the Chesapeake Bay was turned into a state park and is now open to the public. The Department of Environmental Resources Management, Palm Beach County, FL, has multiple wetland island creation and restoration projects ongoing at Snook Island, Peanut Island, and Fullerton Island. Closer to this project area, the SAJ Mile Point study in Jacksonville Harbor is awaiting congressional approval to recreate Great Marsh Island by using dredged material to create 53 acres of low- and high-marsh. Projects like these were once very common in Florida and have recently regained support.

ISLANDS IN THE SUN. Of the 20 million cu yd likely to be dredged from the Jacksonville Harbor GRR, 2.5 million cu yd could be used for the creation of the "Groleau Island Complex" in the Mill Cove area (Figure 2). The main purpose of the Groleau Island Complex is to create valuable, diverse habitat in the St. Johns River ecosystem. The dredged material suitable for island creation is adjacent to the project site. The use of this material for island creation would yield savings of approximately $\$ 10$ million when compared to offshore disposal. This $\$ 10$ million in savings could be critical to the justification of the Jacksonville Harbor GRR.

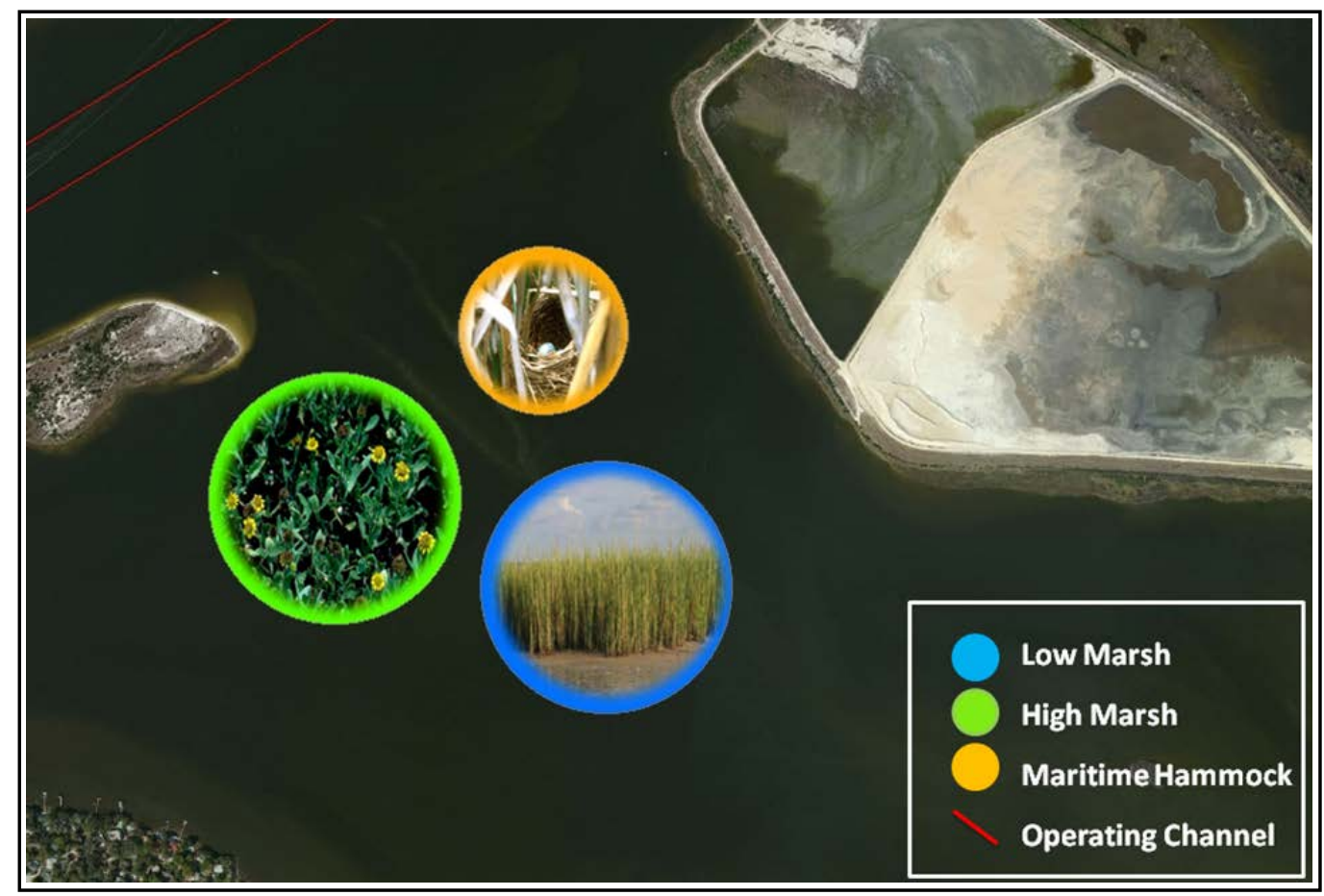

Figure 2. Aerial view of proposed Groleau Islands, J acksonville Harbor, FL. 


\section{J une 2013}

The ideal plan for the Groleau Island Complex is to create a variety of habitats for a diverse range of flora and fauna. This will be accomplished by placing dredged material at different elevations to create three islands: (1) low marsh at approximately -1 ft North American Vertical Datum 1988 (NAVD88), (2) high marsh at approximately +1/2 ft NAVD88, and (3) maritime hammock at approximately +5 ft NAVD88.

Islands would be created by using a turbidity curtain to build a low emergent berm using the sandy material from the nearby channel. This construction should be very similar to how the south and western dikes around Bartram Island Cells A and B were constructed in the 1970s. Hydrodynamic modeling with the Adaptive Hydraulics (AdH) modeling system (USACE 2013) will determine the best location and orientation of the island so that flows in Mill Cove are not reduced. The best case scenario would include improved flows through Mill Cove. The US Army Engineer Research and Development Center, Coastal and Hydraulics Laboratory (ERDC-CHL) developed the twodimensional Adaptive Hydraulics (AdH) Modeling System, which is comprehensively discussed and documented online. A user's manual for applying AdH (Berger et al. 2012) provides further guidance.

The maximum footprint of Groleau Island is approximately 150 acres. All 150 acres are currently unconsolidated river bottom in the Mill Cove area. Rock material from the channel will be used to create complex fish habitat and to serve as a wave breaker. The hard substrate should encourage invertebrate and algal settlement. Although flora will be planted on the islands, natural recruitment is expected based on vegetative growth on similar habitat nearby in the harbor. Among the flora expected are smooth cordgrass, saltwort, needle rush, groundsel tree, live oak, etc. Once the new islands have the desired vegetation, the turbidity fences will be removed so tidal channels will form and stabilize. The diverse habitat is expected to attract seaside sparrows, snowy egrets, alligators, otters, and many other species.

CHALLENGES. Constructing the island complex is a challenging task, from the standpoints of both engineering and environmental coordination. The Jacksonville Harbor GRR is on an accelerated schedule and the agency coordination necessary to get the project permitted could take a significant amount of time. To avoid delays, coordination with environmental agencies began early in the process, and agency preferences were taken into account in the design. There is a chance that an island will settle more than anticipated, or erode away despite geological testing and modeling efforts. If this occurs, suitable material from the next maintenance event would be used to rebuild the island. While SAJ is re-creating (restoring) a similar project at Mile Point, the Groleau Island Complex is actually creation (not restoration) of islands in the St. Johns River. This has not occurred for several years in Florida, but SAJ hopes to resume creating valuable habitat throughout the District.

CONCLUSIONS. SAJ is authorized to beneficially use the navigation dredged material and has the funding to do so since it is the least costly placement plan. When navigation dredged material is not suitable for beach or nearshore placement, it is more beneficial to use the material to create valuable habitat and recreational areas instead of placing the dredged material in offshore or upland areas. The priority is to improve the surrounding ecosystem while simultaneously benefitting the Jacksonville Harbor GRR study, and providing significant cost savings. 
ADDITIONAL INFORMATION. This Coastal and Hydraulics Engineering Technical Note (CHETN) was written by Stephanie Groleau of the US Army Engineer District, Jacksonville, FL as part of the USACE RSM Program. Additional information pertaining to RSM can be found on the RSM web site (http://rsm.usace.army.mil) or by contacting either Stephanie Groleau (904-232-19179) or Matthew Schrader (904-232-2043).

Questions regarding this CHETN may be addressed to:

$\begin{array}{ll}\text { Stephanie M. Groleau } & \text { Stephanie.M.Groleau@usace.army.mil } \\ \text { Matthew H. Schrader } & \text { Matthew.H.Schrader@usace.army.mil } \\ \text { (USACE Jacksonville District RSM POC) } & \\ \text { Linda S. Lillycrop } & \text { Linda.S.Lillycrop@usace.army.mil } \\ \text { (USACE RSM Program Manager) } & \end{array}$

This ERDC/CHL CHETN-XIV-30 should be cited as follows:

Groleau, S. M. 2013. Creation of island habitat in Jacksonville Harbor, FL. Coastal and Hydraulics Engineering Technical Note ERDC/CHL CHETN-XIV-30. Vicksburg, MS: US Army Engineer Research and Development Center, Coastal and Hydraulics Laboratory. http://chl.erdc.usace.army.mil/library/publications/chetn/pdf/chetn-xiv-30.pdf

\section{REFERENCES.}

Berger, R. C., J. N. Tate, G. L. Brown, and G. Savant. 2012. Adaptive hydraulics users manual: Guidelines for solving two-dimensional shallow water problems with the adaptive hydraulics modeling system. Vicksburg, MS: US Army Engineer Research and Development Center, Coastal and Hydraulics Laboratory (ERDC-CHL), http://chl.erdc.usace.army.mil/Media/1/2/7/8/AdH Manual-4.201.pdf

Marine Protection, Research, and Sanctuaries Act. 1972. An act to regulate the transportation for dumping, and the dumping, of material into ocean waters, and for other purposes. Public Law 92-532, 23 October 1972, as amended through Public Law 106-580, 29 December 2000. Enacted by the Senate and House of Representatives of the United States of America in Congress assembled. 33 USC 1401-1445. Washington DC, http://epw.senate.gov/mprsa72.pdf

USACE. 2013. The adaptive hydraulics (AdH) modeling system. Washington DC: US Army Corps of Engineers, https://adh.usace.army.mil/new webpage/main/main page.htm

NOTE: The contents of this technical note are not to be used for advertising, publication, or promotional purposes. Citation of trade names does not constitute an official endorsement or approval of the use of such products. 